\title{
Shifts in phenology of zooplankton due to climate change
}



Fomina Yu.Yu.

Northern Water Problems Institute, Karelian Research Centre, Russian Academy of Sciences

\begin{abstract}
Freshwater zooplankton is recognized as sensitive indicator of environmental changes. Climate change has already altered abundance, species composition, structure of freshwater zooplankton and the timing of seasonal behavior, events and life-history parameters. In recent decades, due to climate warming, the ice-free period, the «biological summer» period, the river runoff have increased in Lake Onego. We have identified 5 phenological phases (winter, spring, early summer, late summer, autumn) on the base of the ratio of the main taxonomic groups of zooplankton using discriminant analysis. The date of the beginning and the end of each phenophase, the duration of the phenological phases were determined. Comparison of long-term data with current data showed a phenological phases shifts. Early summer phenophase has occurred about 30 days earlier. Autumn phenophase has occurred on average 23 days earlier. Knowledge of phenology zooplankton in Petrozavodsk bay of Lake Onego makes it possible to detail the mechanisms of its functioning and to describe the response to climate change.
\end{abstract}

Keywords: phenology, phenological phase, freshwater zooplankton, Onego

There is substantial evidence that climate warming is driving changes in zooplankton. Freshwater zooplankton is recognized as sensitive indicator of environmental changes. Climate change has already altered abundance, species composition, structure of freshwater zooplankton (Adrian and Deneke, 1996; Lazareva and Sokolova, 2013; Izmest'eva et al., 2016), and the timing of seasonal behavior, events and lifehistory parameters (Gerten and Adrian, 2002; Winder et al., 2009; Lazareva and Sokolova, 2013). Phenology is the study of seasonally recurring events in nature and it has been widely used to assess the consequences of climate changes (Vadadi-Fülöp et al., 2012). Lake Onego is a large freshwater reservoir. In recent decades, due to climate warming, the ice-free period, the «biological summer» period, the river runoff have increased in the lake (Filatov et al., 2018).

Petrozavodsk Bay is a large north-western bay of Lake Onego with water surface area about $125 \mathrm{~km}^{2}$ and mean depth $18,5 \mathrm{~m}$. Sampling and laboratory processing were carried out by generally accepted methods (Metodicheskiye rekomendatsii..., 1984). Zooplankton samples were collected using a quantitative Juday plankton net (diameter of $18 \mathrm{~cm}$ and a mesh size of 0,1 $\mathrm{mm})$. The catches were performed by water layers $(0-5$ $\mathrm{m}, 5-10 \mathrm{~m}$, and $10 \mathrm{~m}$-bottom). Fixation was performed with $4 \%$ formalin. Detailed series are needed to study phenology. We used the Database (1988-2011) «Plankton of the pelagic zone of Lake Onego» (Syarki et al., 2015) and current samples collected from 2014 to 2017. Smoothed seasonal trajectory of abundance was obtained using the moving average method in the modification of double smoothing (Syarki, 2013).

The annual zooplankton cycle is characterized by high seasonal fluctuations in relation to abundance and biomass. We examined individual periods (phenophases) in the seasonal dynamics of zooplankton. Each phenophase is characterized by a special species composition, structure and quantity. We have identified 5 phenological phases (winter, spring, early summer, late summer, autumn) on the base of the ratio of the main taxonomic groups of zooplankton using discriminant analysis. The date of the beginning and the end of each phenophase, the duration of the phenological phases were determined (Fomina and Syarki, 2018).

Comparison of long-term data with current data showed that in June 2016 a phenological phase shift was noted. Early summer phenophase has occurred about 30 days earlier than it did in 1988-2011. In the spring of 2016, an extremely high water temperature was observed, it reached $15^{\circ} \mathrm{C}$, while the average water surface temperature in June in the Petrozavodsk Bay is about $6-7^{\circ} \mathrm{C}$. The biomass of phytoplankton and bacterioplankton was lower than long-term average values, the number of saprophytic bacteria was almost 2 times higher. Saprophytic bacteria can be used as indicator of the presence in the water of easily

*Corresponding author.

E-mail address: rambler7780@rambler.ru (Yu.Yu. Fomina)

(C) Author(s) 2020. This work is distributed under the Creative Commons Attribution 4.0 License. 
degradable organic matter introduced by river waters. In our view, phenological shift in the community occurred due to an increase in temperature and the abundance of saprophytic bacteria.

In the first half of August 2014-2017 the community structure corresponded to the autumn phenophase. Autumn phenophase has occurred on average 23 days earlier than it did in 1988-2011. Summer temperatures in 2014-2017 corresponded to long-term average temperatures. The values of bacterioplankton, saprophytic bacteria, and the content of chlorophyll "a" in the 2000s markedly decreased compared to the 1990 s due to a decrease in the anthropogenic load in the bay. Only the total abundance of zooplankton, the abundance of cladoceran and the abundance rotifera were significantly lower than the long-term average values. From our point of view, the shift in autumn phenophase may be associated with a decrease in the level of trophy and / or a shift in the date of the beginning of the late summer phenophase. Further research is required to provide evidence. Dates of other phenological phases have not changed compared to 1988-2011.

Knowledge of phenology zooplankton in Petrozavodsk bay of Lake Onego makes it possible to detail the mechanisms of its functioning and to describe the response to climate change.

The study was conducted in accordance with a state assignment given to the Karelian Research Center of the Russian Academy of Sciences (Northern Water Problems Institute, KRC, RAS).

\section{References}

Adrian R., Deneke R. 1996. Possible impact of mild winters on zooplankton succession in eutrophic lakes of the Atlantic European area. Freshwater Biology 36: 757-770. DOI: 10.1046/j.1365-2427.1996.00126.x

Filatov N.N., Kalinkina N.M., Tekanova E.V. 2018. Modern changes in the ecosystem of Lake Onego with climate warming. Limnology and Freshwater Biology 1: 15-17. DOI: 10.31951/2658-3518-2018-A-1-15
Fomina Yu.Yu., Syarki M.T. 2018. The current state of zooplankton of the Petrozavodsk Bay of Lake Onego and its response to climate change. Trudy Karel'skogo Nauchnogo Tsentra Rossijskoj Akademii Nauk. Seriya Limnologiya i Okeanologiya [Transactions of Karelian Research Center of Russian Academy of Science. Limnology and Oceanology Series] 9: 54-64. DOI: 10.17076/lim820 (in Russian)

Gerten D., Adrian R. 2002. Species-specific changes in the phenology and peak abundance of freshwater copepods in response to warm summers. Freshwater Biology 47: 21632173. DOI: 10.1046/j.1365-2427.2002.00970.x

Izmest'eva L.R., Moore M.V., Hampton S.E. et al. 2016. Lake-wide physical and biological trends associated with warming in Lake Baikal. Journal of Great Lakes Research 42: 6-17. DOI: 10.1016/j.jglr.2015.11.006

Lazareva V.I., Sokolova E.A. 2013. Dynamics and phenology of zooplankton in a large plain reservoir: a response to climate changes. Uspekhi Sovremennoj Biologii [Successes of Modern Biology] 133: 564-574. (in Russian)

Metodicheskiye rekomendatsii po sboru i obrabotke materialov pri gidrobiologicheskikh issledovaniyakh na presnovodnykh vodoyemakh. Zooplankton i yego produktsiya [Methodological recommendations on collection and processing of materials for hydrobiological studies on freshwater reservoirs. Zooplankton and its production]. 1984. In: Vinberg G.G., Lavrent'eva G.M. (Eds.). Leningrad: Gos. Nauchno-Issled. Inst. Ozern. Rechn. Rybn. Khoz. (in Russian)

Syarki M.T. 2013. Studying the trajectory of seasonal dynamics of plankton using the double smoothing method. Principy Ekologii [Principles of Ecology] 1: 61-67. (in Russian)

Syarki M.T., Tekanova E.V., Chekryzheva T.A. 2015. «Plankton of the pelagic zone of Lake Onego». Certificate of state registration of database No. 2015620274. Copyright: Federal State Budgetary Institution of Science Institute of Northern Water Problems of the Karelian Scientific Center of the Russian Academy of Sciences (IWPS KarRC RAS). (in Russian)

Vadadi-Fülöp C., Sipkay C., Meszaros G. et al. 2012. Climate change and freshwater zooplankton: what does it boil down to? Aquatic Ecology 46: 501-519. DOI: 10.1007/ s10452-012-9418-8

Winder M., Schindler D.E., Essington T.E. et al. 2009. Disrupted seasonal clockwork in the population dynamics of a freshwater copepod by climate warming. Limnology and Oceanography 54: 2493-2505. DOI: 10.4319/ lo.2009.54.6_part_2.2493 